\title{
Determination of vulnerability areas from the simulated deposition of atmospheric pollutants using LOTOS-EUROS chemical transport model in North West South America
}

Andrés Yarce Botero ${ }^{1,2,4}$, Santiago Lopez-Restrepo ${ }^{2,4}$, O. L. Quintero ${ }^{2}$, Arjo Segers ${ }^{3}$, Martijn Schaap $^{3}$, Arnold W. Heemink ${ }^{4}$, and Nicolas Pinel ${ }^{1,5}$

${ }^{1}$ Biodiversity, Evolution and Conservation Research Group, Universidad EAFIT. Medellín Colombia

${ }^{2}$ Mathematical Modelling Research Group, Universidad EAFIT. Medellín, Colombia

${ }^{3}$ Department of Climate, Air and sustainability, TNO. Utrecht, The Netherlands

${ }^{4}$ Department of Applied Mathematics, TU Delft. Delft The Netherlands

${ }^{5}$ Department of Biological Sciences, Universidad EAFIT. Medellín, Colombia

Correspondence: Andrés Yarce Botero (a.yarcebotero@tudelft.nl)

\begin{abstract}
.
This work presents the implementation of the LOTOS-EUROS regional atmospheric Chemical Transport Model (CTM) on Northwestern South America. The impact of land use and orography update in the model was analyzed to identify potential vulnerable natural areas by quantifying atmospheric deposition pollutants. CTMs allow simulating the physical dynamics of trace gasses and aerosols, including processes such as emission, chemical reactions, transport, and deposition. The deposition of atmospheric contaminants like nitrogen dioxide $\left(\mathrm{NO}_{2}\right)$ and ammonia $\left(\mathrm{NH}_{3}\right)$ induces chemical fluxes in natural ecosystems, with potential subsequent severe impacts like biodiversity loss. Due to the vast geographical diversity present in the study area, the LOTOS-EUROS model was updated for the land and topography inputs to simulate more representative conditions for the study region. Depositions were very sensitive for the change of land cover maps used in the model, and on the other side, topography update impacts more in the high layer of the model above harsh terrain. Additional simulations for the updated scenario using point sources were performed to identify the deposition area's spatial extent for the principal Colombian cities.
\end{abstract}

Keywords : LOTOS-EUROS, Depostion, Natural protected areas, Point sources, land use update.

Copyright statement. TEXT

\section{Introduction}

Atmospheric deposition is described as the mechanism that induces a flux of gasses and particles to the land surface due to meteorological, chemical, and biological phenomena (Giardina and Buffa, 2018). Through atmospheric transport and deposition, emitted pollutants can alter the dynamics of remote ecosystems (Bard (1999); Fowler et al. (1999)). Anthropogenic activities 
This paper is a non-peer reviewed preprint submitted to EarthArXiv.

are significant sources of reactive nitrogen $\left(\mathrm{N}_{\mathrm{r}}\right)$ to the atmosphere (Fowler et al., 2013). Photochemical reactions of $\mathrm{NO}_{\mathrm{x}}$ and

$\mathrm{NH}_{3}$ create secondary inorganic aerosols (Erisman et al., 2005) that can be transported over large distances (Jia et al., 2016).

Long-distance transport of secondary inorganic aerosol accounts for over $8 \%$ of the planet's reactive nitrogen flow in terrestrial ecosystems (Fowler et al., 2013), and a significant source of $\mathrm{N}_{\mathrm{r}}$ to the ocean (Duce et al., 2008). Deposition of atmospheric $\mathrm{N}_{\mathrm{r}}$ alters oligotrophic ecosystems (Erisman et al., 2005, 2013), affecting the distribution of communities of species (Bobbink et al., 2010; Farrer and Suding, 2016; Maskell et al., 2010; Simkin et al., 2016; Stevens et al., 2004) and ecosystem stability (Koerner et al., 2016). $\mathrm{NO}_{2}$ is a gas emitted by anthropogenic and natural sources as part of the family of the nitrogen oxides $\mathrm{NO}_{x}\left(\mathrm{NO}+\mathrm{NO}_{2}\right)$ emmited from anthropogenic (industrial activity, transport and biomass burning) and natural ( $\mathrm{NO}_{x}$ soil emissions and lighting) sources. Agricultural activities and livestock feedlot operations are the primary causes of atmospheric $\mathrm{NH}_{3}$, followed by wood burning (including forest fires) and fossil fuel combustion to a lesser degree. Acute exposures to $\mathrm{NH}_{3}$ near its origin (4-5 km) can lead to substantial foliar damage to the plant, growth and productivity decreases (Krupa, 2003).

30 This study focuses on atmospheric transport and deposition of $\mathrm{N}_{\mathrm{r}}$, primarily nitrogen dioxide $\left(\mathrm{NO}_{2}\right)$ and ammonia $\left(\mathrm{NH}_{3}\right)$, over Northwest South America, and in particular over Colombia. The country lacks a ground network for measuring atmospheric nitrogen, except for sparse air quality monitoring networks in the main urban centers (Barten et al., 2019). Measurements of deposited nitrogen are not available. Due to the lack of observations, simulation models such as Chemical Transport Models (CTMs) are essential for understanding the spatial and temporal dynamics of reactive nitrogen over Colombia. CTMs simulate the dynamic concentrations of trace gasses and aerosols as influenced by processes such as emission, chemical reactions, transport, and deposition.

The use of CTM's in the Tropical Andean Region (including NW South America) has been recently reviewed ((Quintero Montoya et al., 2020)), highlighting the difficulties involved in modeling atmospheric chemistry and transport in tropical regions with abrupt topography. Additional applications have included primarily the use of the WRF-Chem CTM for evaluating the dynamics behind high $\mathrm{PM}_{1} 0$ and $\mathrm{PM}_{2} .5$ episodes under different meteorological conditions for the city of Bogotá (Casallas et al., 2020); the exploration of methane emission sources with the use of satellite data (Verkaik and Ganzeveld, 2019), and the dispersion of CO within the Aburrá Valley (Henao et al., 2020). Work currently under review on the use of WRF-Chem and OMI-generated satellite (Barten et al., 2019), estimated $\mathrm{NO}_{\mathrm{x}}$ sources and sinks in Colombia for 2014 at a $1^{\circ}$ x $1^{\circ}$ resolution and identified lighting as the main contributor to the total nitrogen emission budget. Lastly, surface $\mathrm{NO}_{2}$ concentrations for Colombia in 2007 where estimated from simulations of the global model GEOS-Chem CTM (resolution $2.5^{\circ} \times 2^{\circ}$ ) and OMI $\mathrm{NO}_{2}$ column measurements, resulting in the identification of biomass burning as a significant source of atmospheric $\mathrm{NO}_{2}$ Grajales and Baquero-Bernal (2014). In this study, we conducted a qualitative and quantitative analysis of the spatial and temporal patterns of deposition nitrogen dioxide $\left(\mathrm{NO}_{2}\right)$ and ammonia $\left(\mathrm{NH}_{3}\right)$ over the Colombian domain using the LOTOSEUROS CTM.

\subsection{The LOTOS-EUROS Chemical Transport Model}

The model used was the LOTOS-EUROS (LOng Term Ozone Simulation- EURopean Operational Smog model) v2.0.001 to simulate in three dimensions the atmospheric species of the lower layers of the troposphere. The dynamics of the species in the 
This paper is a non-peer reviewed preprint submitted to EarthArXiv.

model is regulated by processes of chemical reactions, diffusion, drag, dry and wet depositions, emissions and advection. The model has been used in various studies simulating trace gas and aerosol concentrations (Timmermans et al., 2017; Petersen et al., 2019; Kociok et al., 2018). The model is used for daily operational air quality forecasts over Europe (Marécal et al., 2015), the Netherlands (Hendriks et al., 2013), and China (Brasseur et al., 2019). The model is used for daily forecasts of dust concentrations over north Africa as part of the SDS-WAS service (Dominguez-Rodriguez et al., 2020), and has been used to forecast the dynamics of particulate matter in the Aburrá Valley in Colombia (Lopez-Restrepo et al., 2020).

\subsection{Deposition of pollutants}

60 Among the various removal mechanism of pollutants in the atmosphere, dry deposition is an important mechanism that comprises a large part of the total deposition (Graaf et al., 2018). Deposition of gases is a diffusion flux driven by a difference in concentrations inside and outside the vegetation tissues. Deposition can occur directly into the soil, but is much stronger on vegetation surfaces. The primary surfaces for deposition are the leaves, where gasses and particles can be absorbed via the stomata or the cuticle (Wesely, 1989), though outer bark surfaces can also contribute. In LOTOS-EUROS the resistance approach is used to simulate gas-phase deposition following the DEPAC (DEPosition of Acidyfing Compounds) formulation (Van Zanten et al., 2010). The DEPAC module takes into account three pathways: deposition through the stomata, deposition through the external leaf surface, and deposition through the soil, to calculate the deposition velocities for each one of the categories. The model takes into account the exchange of components between the lower layers of the atmosphere and surfaces for estimating deposition. The flux of components encourages this exchange because of the difference in the concentration produced between the atmosphere and the surface of the Earth (Manders-Groot et al., 2016a). For deposition of aerosols, a uniform structure for all land-use categories over the analysis is used (Manders-Groot et al. (2016b)) with an explicit dependence on aerosol size Zhang et al. (2001).

The atmospheric species' deposition simulation is a challenging task highly dependent on whether the phenomena are modeled in the near, local, or long-field range. Larger particles dominate a near-field deposition. Local field events occur in the plume portion dominated by the wind-driven trajectory where the peak-to-mean concentration ratios are much smaller than closer to the source, resulting in more uniform deposition patterns. In long-range fields, the larger particles have been removed, so smaller particles are the primary concern of the modeling (Droppo, 2006). The parameters that describe the deposition phenomena are highly uncertain, especially when land use and vegetation type data are low in detail or spatial resolution. Existing atmospheric deposition models might not be appropriate for simulating deposition fluxes around urbanized environments, which present varied and rapidly changing forms of land use (Chérin et al., 2015). This study focuses on updating the land use data on the estimates of nitrogen deposition in Colombia. Whereas previous studies were limited by the use of relatively coarse spatial resolutions (Grajales and Baquero-Bernal, 2014; Barten et al., 2019), a resolution of $0.09^{\circ} \mathrm{x} 0.09^{\circ}$ was used to increase the level of detail in the simulations. The sensitivity to input (land use and topography) modifications was studied to determine the impacts on the model deposition predictions. Additionally, point source experiments were conducted to understand the spatial deposition dynamics of $\mathrm{N}_{\mathrm{r}}$ emanating from the principal urban areas of the country. This work contributes to assessing the performance of the LOTOS-EUROS CTM in NW South America. 
This paper is a non-peer reviewed preprint submitted to EarthArXiv.

\section{Methodology}

\subsection{Model Set Up}

Two nested domains (see Fig. 1) were used for simulations to provide higher resolution boundary conditions for the area of interest. The configuration for the simulations is detailed in 1 . The first domain (D1) stretched from the west coast of Nicaragua to the Caribbean Dutch Islands and Eastern Venezuela, with a horizontal resolution of $0.27^{\circ}$ (about $28 \mathrm{~km}$ ). The inner domain (DCol) covered the continental territory of Colombia, with a horizontal resolution of $0.09^{\circ}(\approx 10 \mathrm{~km})$. All deposition analyses were conducted in the inner domain.

\begin{tabular}{|c|c|}
\hline Period & 1-January-2016 to 31-December-2016 \\
\hline Meteorology & ECMWF; Temp. res.: 3h; Horiz. res.: $0.07^{\circ} \times 0.07^{\circ}$ \\
\hline $\begin{array}{c}\text { Initial and boundary } \\
\text { conditions }\end{array}$ & $\begin{array}{c}\text { LOTOS-EUROS (D1). Temp. res.: } 1 \mathrm{~h} . \\
\text { Horiz. res.: } 0.09^{\circ} \times 0.09^{\circ}\end{array}$ \\
\hline Anthropogenic emissions & EDGAR v4.2. Spat. res.: $10 \mathrm{~km} \times 10 \mathrm{~km}$ \\
\hline Biogenic emissions & MEGAN Spat. res.: $10 \mathrm{~km} \times 10 \mathrm{~km}$ \\
\hline Fire emissions & MACC/CAMS GFAS Spat. res.: $10 \mathrm{~km} 10 \mathrm{~km}$ \\
\hline Landuse & GLC2000. Spat. res.: $1 \mathrm{~km} \times 1 \mathrm{~km}$ \\
\hline Orography & GMTED2010. Spat. res: $0.002^{\circ} \times 0.002^{\circ}$ \\
\hline Domain 1 (D1) Lat x Lon & {$\left[-8.5^{\circ}, 18^{\circ}\right] \times\left[-84^{\circ},-60^{\circ}\right]$} \\
\hline Domain Colombia (DCol) Lat $x$ Lon & {$\left[-4.55^{\circ}, 13.27^{\circ}\right] \times\left[-79.80^{\circ},-65.94^{\circ}\right]$} \\
\hline
\end{tabular}

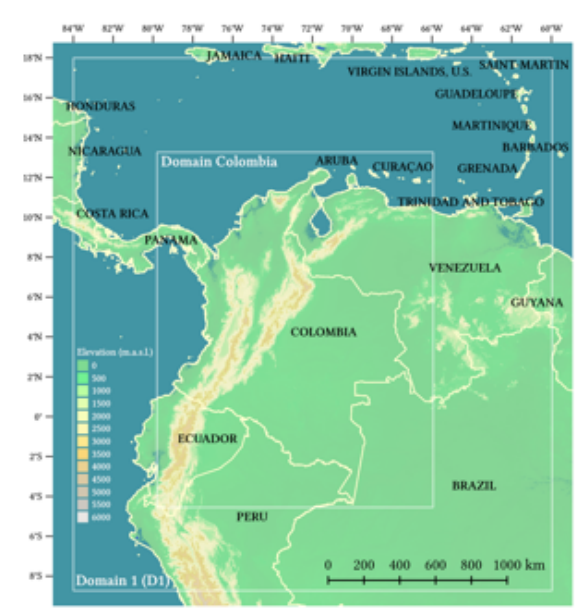

Figure 1. Nested domain model configuration selected for the LOTOS-EUROS simulations over North West South America D1 $\left(0.27^{\circ}\right)$ and $\operatorname{Dcol}\left(0.09^{\circ}\right)$.

The model follows a mixed-layer level approach with a $25 \mathrm{~m}$ surface layer, a mixed layer with a top at the boundary layer height taken from the meteorological input, and two reservoir layers of at least $500 \mathrm{~m}$. When the mixing layer is very thick, such as over mountainous terrain in the tropics where elevations can regularly reach heights of more than $3500 \mathrm{~m}$, the top of the model is extended to accommodate the minimum thickness of the reservoir layers. The deposition process is dominated by the interaction of the static surface layer.

The default elevation model for LOTOS-EUROS is obtained from the ECMWF meteorological data, which has a resolution of $0.07^{\circ}(\approx 7 \mathrm{~km})$. An updated elevation model used for the region was obtained from the Global Multi resolution Terrain Elevation Data (GMTED 2010) (Danielson and Gesch, 2011), with a resolution of $0.002^{\circ}(\approx 220 \mathrm{~m})$. Figure 2 shows a comparison between the default and the updated elevation model. The inset zoomed in around the Aburrá Valley (Medellín and neighboring municipalities) demonstrates how the valley is absent in the default elevation model.

A regionally detailed and up-to-date anthropogenic emissions inventory for the time of the simulations was not available. Therefore emissions were taken from EDGAR (Emission Database for Global Atmospheric Research) 4.2 for 2008. However, 


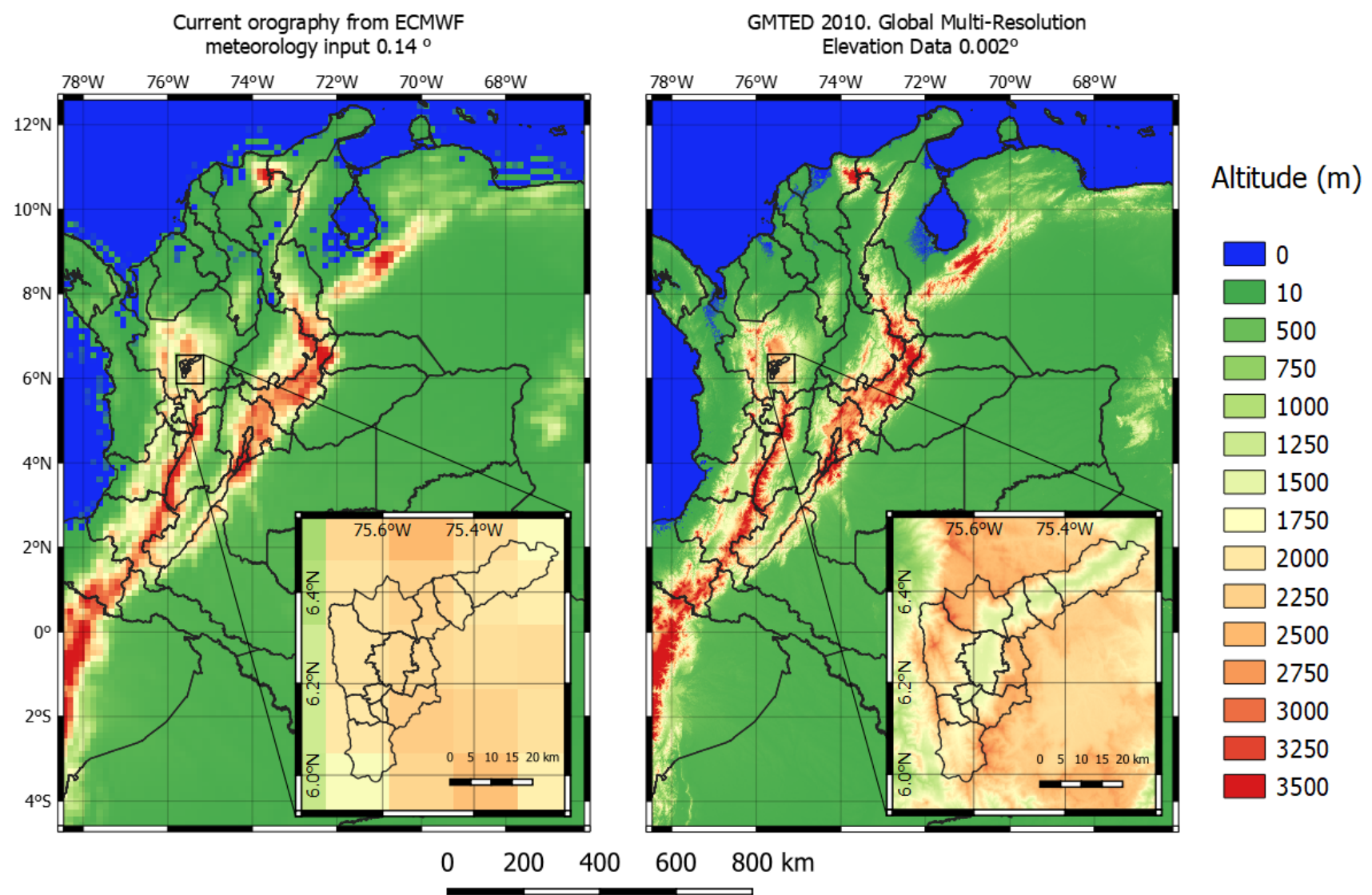

Figure 2. Comparison between the default elevation model for LOTOS-EUROS (A) and the updated elevation model derived from the GMTED 2010 data (B). The insets illustrate the differences in elevation representation for the Aburrá Valley.

previous studies have shown a significant gap in knowledge for the Colombian territory in the EDGAR inventory (e.g., (Gonzalez et al., 2017; Pachón et al., 2018; Nedbor-Gross et al., 2018)), this database was at the time the only one accessible with all the species required to operate the model in the selected domain for the time of the simulations. Biogenic emissions were taken from the MEGAN 2.1 model. The MACC/CAMS GFAS global fire assimilation system from Kaiser et al. (2012) was used with a time resolution of 1 hour to account for the occasional fire events. The chemical mechanism used was the Carbon Bond mechanism 5 (CB05), and the sea salt emissions were parameterized according to formulations for the fine and coarse aerosol modes from (Monahan et al., 1986) and (Mårtensson et al., 2003). 
This paper is a non-peer reviewed preprint submitted to EarthArXiv.

\subsubsection{Land Cover/Land Use data}

For modeling the deposition dynamics, LOTOS-EUROS requires a map with deposition properties per grid cell. Land use characteristics are relevant for the CTM deposition dynamics because they define the parameters of the terrain roughness and canopy altitude of each category that determine the velocity at which the component will be deposited, dependent on the vegetation type. The default land use/land cover (LU/LC) input data for LOTOS-EUROS were derived from the Global Land Cover (GLC2000) project (Fritz et al., 2003). GLC includes 23 categories consistent with the FAO (Land Cover Classification System of the Food and Agriculture Organization) classification (Di Gregorio, 2005). For South America, the mapping of these categories at spatial resolutions of $1 \mathrm{~km} \mathrm{x} 1 \mathrm{~km}$ was done in (Eva et al., 2002), with contributions from some regional experts based on multi-resolution satellite data. In this work, the LU/LC data was updated with the 2009 Land Cover Climate Change Initiative (CCI) dataset (Defourny et al., 2017). CCI has 38 categories with a horizontal resolution of $300 \mathrm{~m} \times 300 \mathrm{~m}$. Figure 3 compares the default and updated LU/LC models for Aburrá Valley. The mapping of the 39 (CCI) and 23 (GLC) LU/LC categories to the nine classes of the DEPAC deposition model is illustrated in Figure 4. The descriptions of each category are presented in Table 1. The mapping from CCI to GLC took into account the similar morphological characteristics between categories and the aseasonality in this tropical region. The mapping from GLC to DEPAC is the standard scheme constructed for LOTOS EUROS. The model defines each grid cell the fraction covered by each of the LU/LC classes used by the DEPAC module and calculates each fraction's deposition.

\subsection{Experiment description}

Simulations were conducted with the following inputs: Experiment 1 (Exp-1), default elevation model and default LU/LC data; Experiment 2 (Exp-2), default elevation model and updated LU/LC data; Experiment 3 (Exp-3), updated elevation model and default LU/LC data; and Experiment 4 (Exp-4), updated elevation model and updated LU/LC data. For each of these four experiments, the total deposition (wet and dry) nitrogen dioxide $\left(\mathrm{NO}_{2}\right)$ and ammonia $\left(\mathrm{NH}_{3}\right)$ was calculated for the entire 2016. Zonal analysis for estimating annual nitrogen deposition in protected areas and páramo ecosystems were conducted in QGIS 3.10 (https://qgis.org), using official Colombian cartography obtained from the National Geographic Information Systems (SIGOT, https://sigot.igac.gov.co/).

\subsection{Fate of urban contaminants experiments}

To explore the fate of nitrogenous atmospheric species emitted from the main Colombian cities, the grid cells housing the centroids of the urban area for Bogotá, Medellín, Cali, and Barranquilla were assumed as artificial point sources of emissions. The simulations were conducted with the updated elevation model and updated LU/LC scheme detailed above, for a total of 10 days in four different times of the year: March 1-10, June 1-10, September 1-10, and December 1-10. After a 2-day model spin up, the point source was from 08:00-18:00 of day 3 of the simulation, emitting a total of $1000 \mathrm{~kg} /$ hour $\mathrm{NO}_{2}$, which is the amount of daily $\mathrm{NO}_{2}$ emissions reported for Medellń (UPB and AMVA, 2017). The artificial emissions were monitored during 


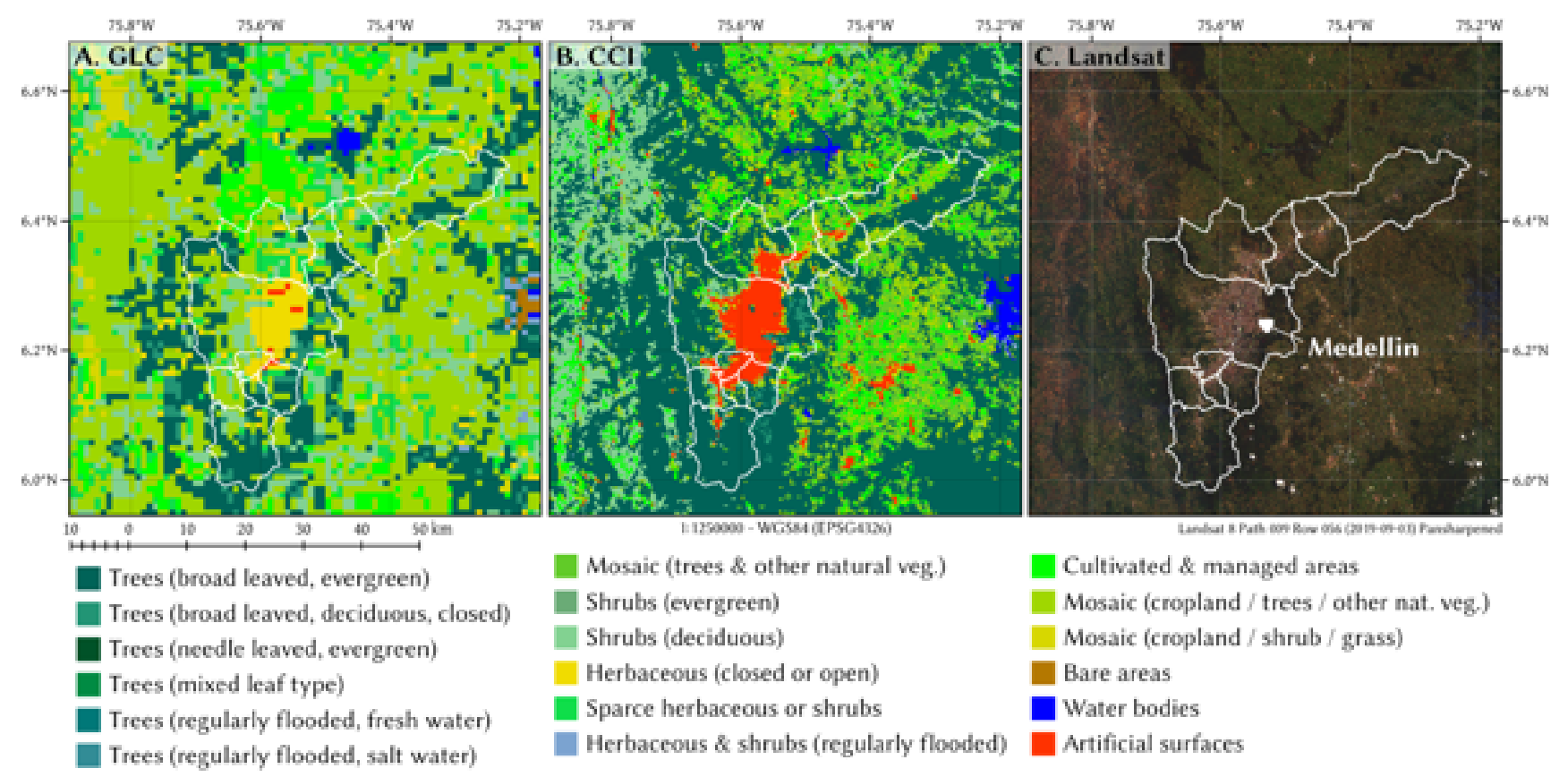

Figure 3. Comparison between (A) the LOTOS-EUROS's original land cover model (Global Land Cover, with resolution of $1 \mathrm{~km} \times 1 \mathrm{~km}$.) and (B) the updated land cover scheme (Land cover from the Climate Change Initiative, with resolution $0.3 \mathrm{~km} \mathrm{x} 0.3 \mathrm{~km}$ ). Real color Landsat cloudless imagery for the date 2019-09-03 is included in (C) as a reference for the artificial surfaces from the city infrastructure. The political boundaries correspond to the municipality of Medellín and the other nine municipalities that constitute the Aburrá Valley Metropolitan Area conurbation.

seven additional days, during which time all of the emitted species had either deposited or transformed. Similar simulations were conducted but without the point source's activation to estimate the background deposition values for each grid cell.

A second experiment was conducted as above, but focusing on either Medellín or Rionegro. The latter city is located at the East of the Aburrá Valley, near the international airport that serves Medellín and the immediate region. Rionegro is the largest and fastest-growing city in the Valley of San Nicolás. The urban growth in this region is being fueled in part by the migration of people from the Aburrá Valley. Many residents in the Valley of San Nicolás hold jobs inside the Aburrá Valley, and many schools that serve middle and upper-income families from the Aburrá Valley are located in the San Nicolás Valley. The second experiment aimed to understand the potential implications for regional $\mathrm{N}_{\mathrm{r}}$ deposition derived from increase urban development in the Valley of San Nicolás. 
This paper is a non-peer reviewed preprint submitted to EarthArXiv.

\begin{tabular}{|c|c|c|c|c|c|}
\hline Number & Land Cover Climate Change Initiative (CCI) label & Code CCI & Number & Global Land Cover (GLC) label & Code CORINE \\
\hline 0 & No data & ND & 1 & Tree Cover, broadleaved, evergreen & TBE \\
\hline 10 & Cropland, rainfed & CRA & 2 & Tree Cover, broadleved, deciduous, closed & TBDC \\
\hline 11 & Herbaceous cover & $\mathrm{HBC}$ & 3 & Tree Cover, broadleaved, deciduous, open & TBDO \\
\hline 12 & Tree or shrub cover & TSC & 4 & Tree Cover, needle-leaved, evergreen & TNE \\
\hline 20 & Cropland, irrigated or post-flooding & CIP & 5 & Tree Cover, needle-leaved, deciduous & TND \\
\hline 30 & Mosaic cropland $(>50 \%) /$ natural vegetation (tree, shrub, herbaceous cover) $(<50 \%)$ & $\mathrm{MC} / \mathrm{NV}$ & 6 & Tree Cover, mixed leaf type & TML \\
\hline 40 & Mosaic natural vegetation (tree, shrub, herbaceous cover) $(>50 \%) /$ cropland $(<50 \%)$ & MNV & 7 & Tree Cover, regularly flooded, fresh water & TRF \\
\hline 50 & Tree cover, broadleaved, evergreen, closed to open ( $>15 \%)$ & TBECO & 8 & Tree Cover, regularly flooded, saline water & TRS \\
\hline 60 & Tree cover, broadleaved, deciduous, closed to open $(>15 \%)$ & TBDCO & 9 & Mosaic: Tree Cover / Other natural vegetation & MTO \\
\hline 61 & Tree cover, broadleaved, deciduous, closed ( $>40 \%)$ & TBDC & 10 & Tree Cover, burnt & TCB \\
\hline 62 & Tree cover, broadleaved, deciduous, open (15-40\%) & TBDO & 11 & Shrub Cover, closed-open, evergreen & SCOE \\
\hline 70 & Tree cover, needleleaved, evergreen, closed to open $(>15 \%)$ & TNECO & 12 & Shrub Cover, closed-open, deciduous & SCCD \\
\hline 71 & Tree cover, needleleaved, evergreen, closed $(>40 \%)$ & TNEC & 13 & Herbaceous Cover, closed-open & $\mathrm{HCCO}$ \\
\hline 72 & Tree cover, needleleaved, evergreen, open (15-40\%) & TNEO & 14 & Sparse herbaceous or sparse shrub cover & SHSS \\
\hline 80 & Tree cover, needleleaved, deciduous, closed to open $(>15 \%)$ & TNDCO & 15 & Regularly flooded shrub and/or herbaceous cover & RFSH \\
\hline 81 & Tree cover, needleleaved, deciduous, closed ( $>40 \%)$ & TNDC & 16 & Cultivated and managed areas & CMA \\
\hline 82 & Tree cover, needleleaved, deciduous, open $(15-40 \%)$ & TNDO & 17 & Mosaic: Cropland / Tree Cover / Other natural vege & MCTO \\
\hline 90 & Tree cover, mixed leaf type (broadleaved and needleleaved) & TMBN & 18 & Mosaic: Cropland / Shrub and/or grass cover & CSG \\
\hline 100 & Mosaic tree and shrub $(>50 \%) /$ herbaceous cover $(<50 \%)$ & MTS & 19 & Bare areas & BAR \\
\hline 110 & Mosaic herbaceous cover $(>50 \%) /$ tree and shrub $(<50 \%)$ & MHC & 20 & Water bodies & WAB \\
\hline 120 & Shrubland & SRU & 21 & Snow an Ice & SNI \\
\hline 121 & Shrubland evergreen & SRE & 22 & Artificial surfaces and associated areas & URB \\
\hline 122 & Shrubland deciduous & SHD & 23 & No Data & ND \\
\hline 130 & Grassland & GRA & Number & LOTOS-EUROS fractional categories & LE-fract-code \\
\hline 140 & Lichens and mosses & LIM & 1 & Arable & ARA \\
\hline 150 & Sparse vegetation (tree, shrub, herbaceous cover) $(<15 \%)$ & SPV & 2 & Permanent crops & CRP \\
\hline 151 & Sparse tree $(<15 \%)$ & SPT & 3 & Grass & GRS \\
\hline 152 & Sparse shrub $(<15 \%)$ & SPS & 4 & Coniferous forest & $\mathrm{CNF}$ \\
\hline 153 & Sparse herbaceous cover $(<15 \%)$ & $\mathrm{SHC}$ & 5 & Decidious forest & DEC \\
\hline 160 & Tree cover, flooded, fresh or brackish water & TFFB & 6 & Other & OTH \\
\hline 170 & Tree cover, flooded, saline water & TFS & 7 & Water & WAT \\
\hline 180 & Shrub or herbaceous cover, flooded, fresh/saline/brackish water & SHCF & 8 & Urban & $\mathrm{NO} 2$ \\
\hline 190 & Urban areas & URB & 9 & Desert & DSR \\
\hline 200 & Bare areas & BAR & & & \\
\hline 201 & Consolidated bare areas & CBA & & & \\
\hline 202 & Unconsolidated bare areas & UBA & & & \\
\hline 210 & Water bodies & WAB & & & \\
\hline 220 & Permanent snow and ice & SNI & & & \\
\hline
\end{tabular}

Table 1. Land Use/ Land Cover categories for the two sources of data used in this study and for the DEPAC module.

\section{Results}

\subsection{Updated elevation model}

155 LOTOS-EUROS interpolates the input elevation data within each grid cell according to the simulation's resolution (Fig. A1). Changing the input elevation model can generate changes in the outcome of variables such as the vertical layers' temperature profiles. The effect of an updated elevation model depends on the desired simulation grid resolution. Figure 5 shows a transverse cut at a latitude of $6.6^{\circ}$ North for the simulation at a horizontal resolution of $0.09^{\circ} \times 0.09^{\circ}$, illustrating the impact of the change 
38 Categories $\mathrm{CCl}$

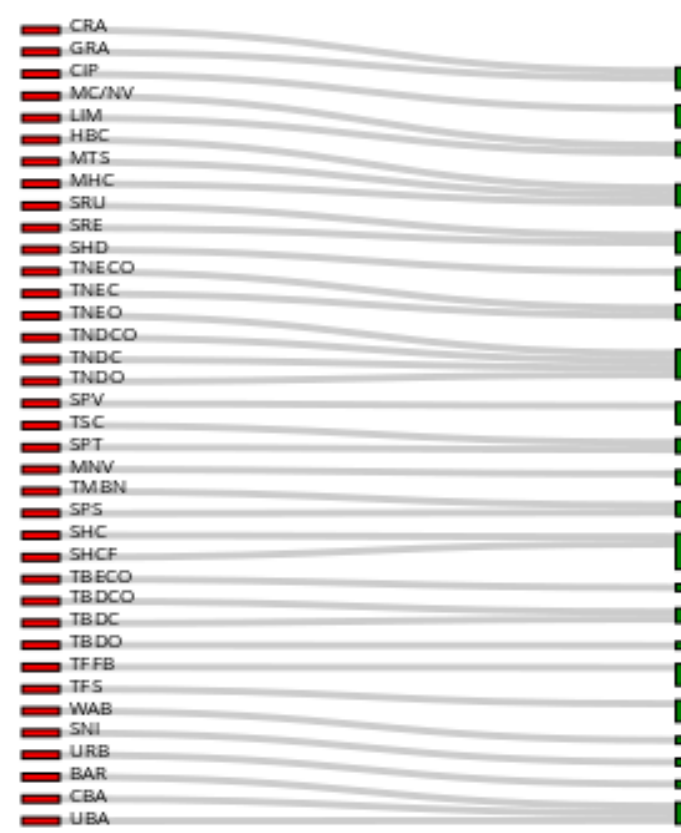

23 Categories GLC

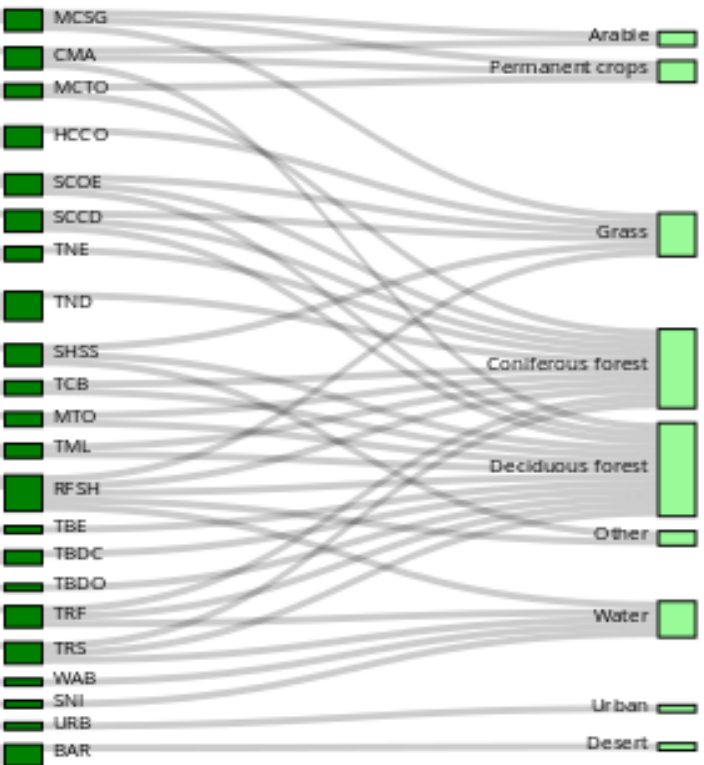

Figure 4. Climate Change Initiative (CCI) Land Cover data categories mapped to the Global Land Cover (GLC). The GLC categories are in turned mapped to the model's equivalencies. The category's codes are as in Table 1.

of input elevation information through the Aburrá Valley. The most significant temperature changes occurred in the upper layers above the rugged terrain, reaching differences of up to $5^{\circ} \mathrm{C}$ degrees in top layers.

\subsection{Conversion of categories}

Figure 6 compares the fractional coverage changes of the 23 categories of the GLC2000 land use when using the CCI land use data and the mapping presented in Figure 4. Image (A) compares the total area represented by each category over the entire study domain. Image (B) shows the fractional bias error calculations between these scenarios for all the simulation domains, illustrating the fractional change for each category. LOTOS-EUROS allocates a fractional usage per grid of the land surface to each of the nine categories used by DEPAC to generate the corresponding deposition estimates.

Figure 7 shows the mean fractional bias of the updated CCI land cover model relative to the default GLC LU/LC data. Changes were noticeable for categories like grasslands where the deposition decreased with the updated land-use configuration. For categories such as deciduous forest, arable, coniferous forest, and permanent crops, mostly located in the Eastern region of the country, the simulations showed an increase in depositions related to the change in the fraction percentage of these categories. 

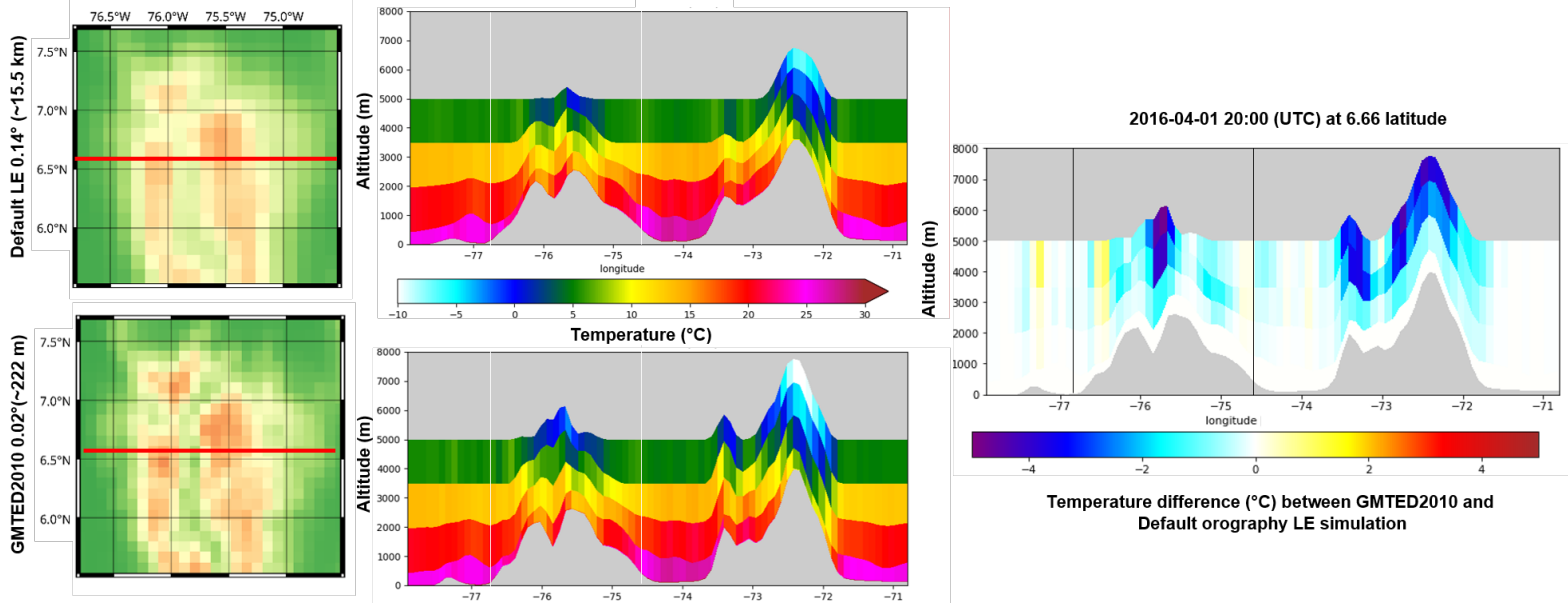

Figure 5. Transversal cut at $6.6^{\circ} \mathrm{N}$ for vertical temperature profile comparison
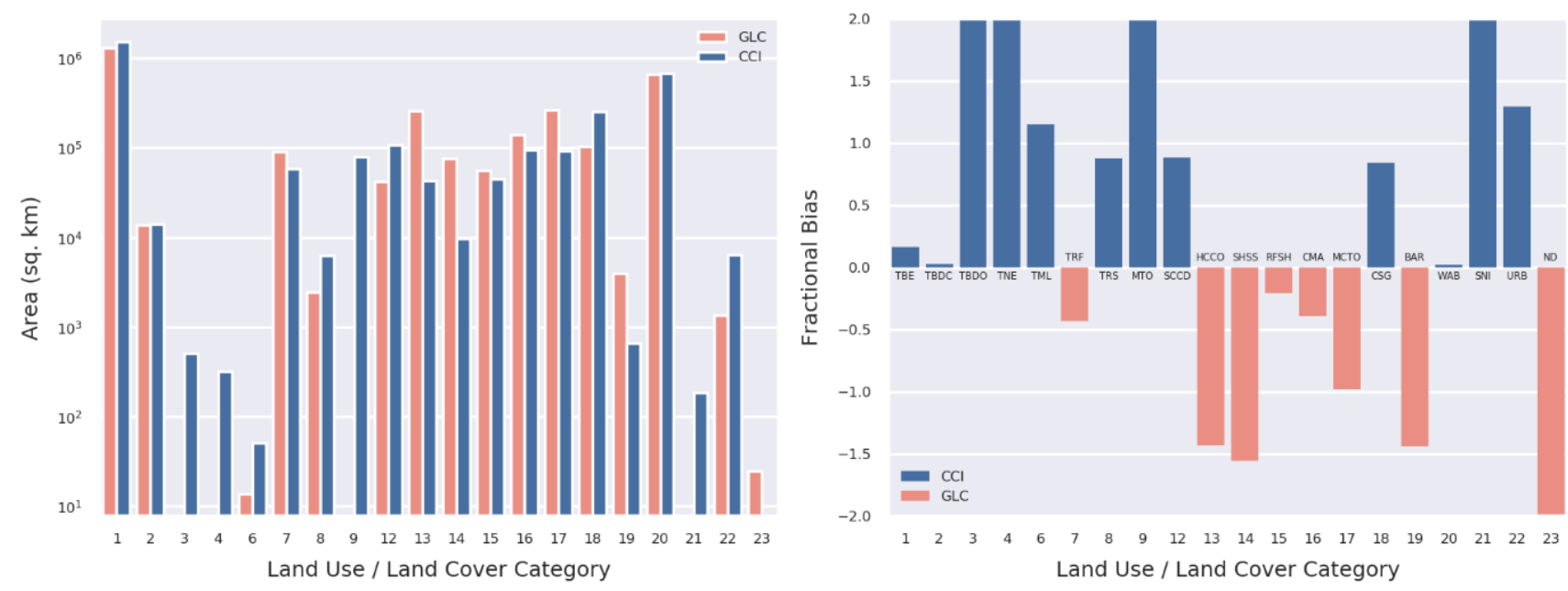

Figure 6. a) Comparison of the area between categories from both land uses b) Fractional Bias comparison

The Amazon region (SE) presented minimal changes in deposition between the two LU/LC scenarios, primarily due to the negligible changes in LU/LC between the two data sources. The highest changes were found along the Andean cordilleras related to deposition in deciduous and coniferous forest, which were higher in the updated LU/LC scheme. 

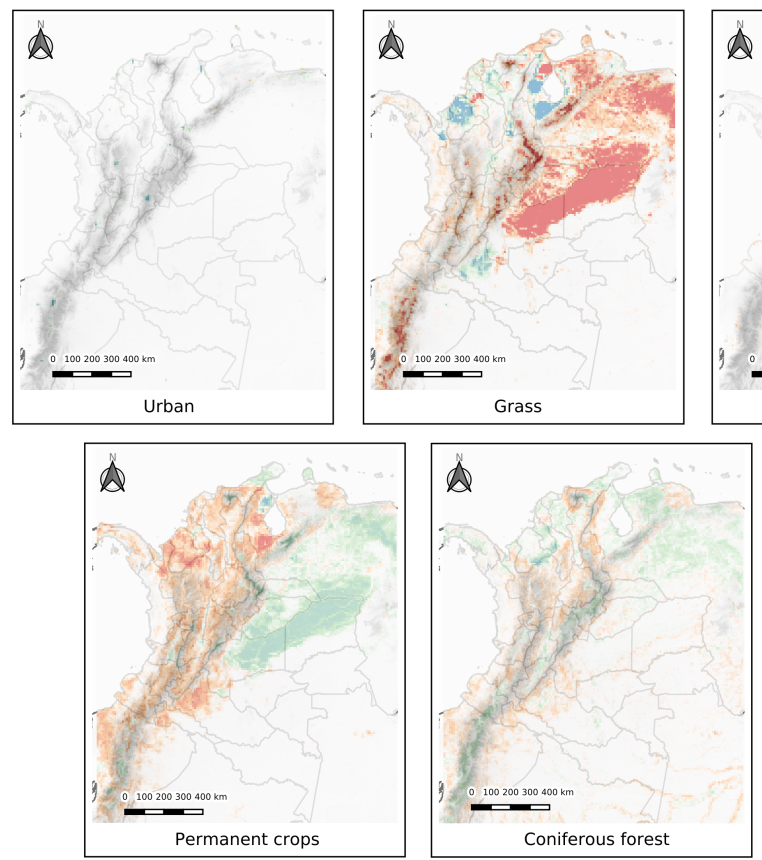
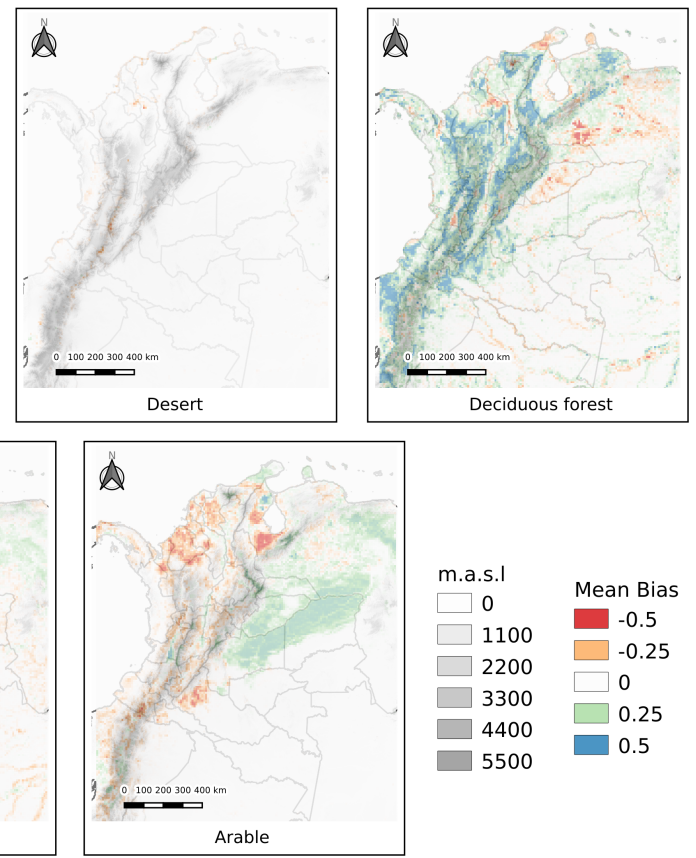

Deciduous fores

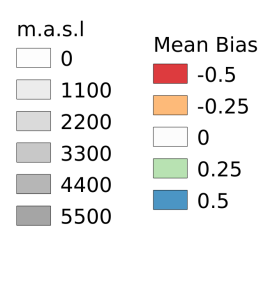

Figure 7. DEPAC categories Mean Bias. Only 7 of 9 categories are shown here. The other two are the categories water and other

\subsection{Deposition zones}

The pictures in 8 show the comparison between the different scenarios for the $\mathrm{NO}_{2}$ and $\mathrm{NH}_{3}$ accumulated dry deposition for the year 2016 simulated with the LOTOS-EUROS CTM. The upper left corner of each situation corresponds to Exp- 1 (as defined in the Methods section), and the lower right corner corresponds to the Exp-4 conditions. The top right images correspond to the MFB comparison between Exp-1 and Exp-2 and lower left to the same MFB comparison between Exp-1 and Exp-3 elucidating the impact on the total deposition for 2016 due to the change in land use and orography scenarios respectively. MFB comparisons allowed us to highlight some regions (A, B, C, and D) of interest due to some drastic changes presented there that overestimate or underestimate deposition values concerning the initial condition presented in the Exp-1.

Figure (A3 shows the land use comparison for the respective chemical compound simulation deposition output. For zone A, The water bodies category of the CCI land use are more abundant than the GLC, where the regularly flooded shrub and herbaceous cover are predominant in the bodies of internal waters. The three cover categories and the urban areas are noticeable in the zones with an overestimation from the MFB image. On the other hand, the bare areas and the three cover and regularly flooded, and the cultivated and managed areas and mosaic cropland are more abundant in the old land cover. For zone $\mathrm{C}$, the urban areas are more relevant in the updating of land use. It seems the land use located at the left of the principal urban area of the images that correspond to cultivated and managed areas seems to promote the deposition in a more significant way on the update condition. Moreover, in Fig. (A3, E), we can see that the herbaceous cover closed-open was prevalent in the old land 


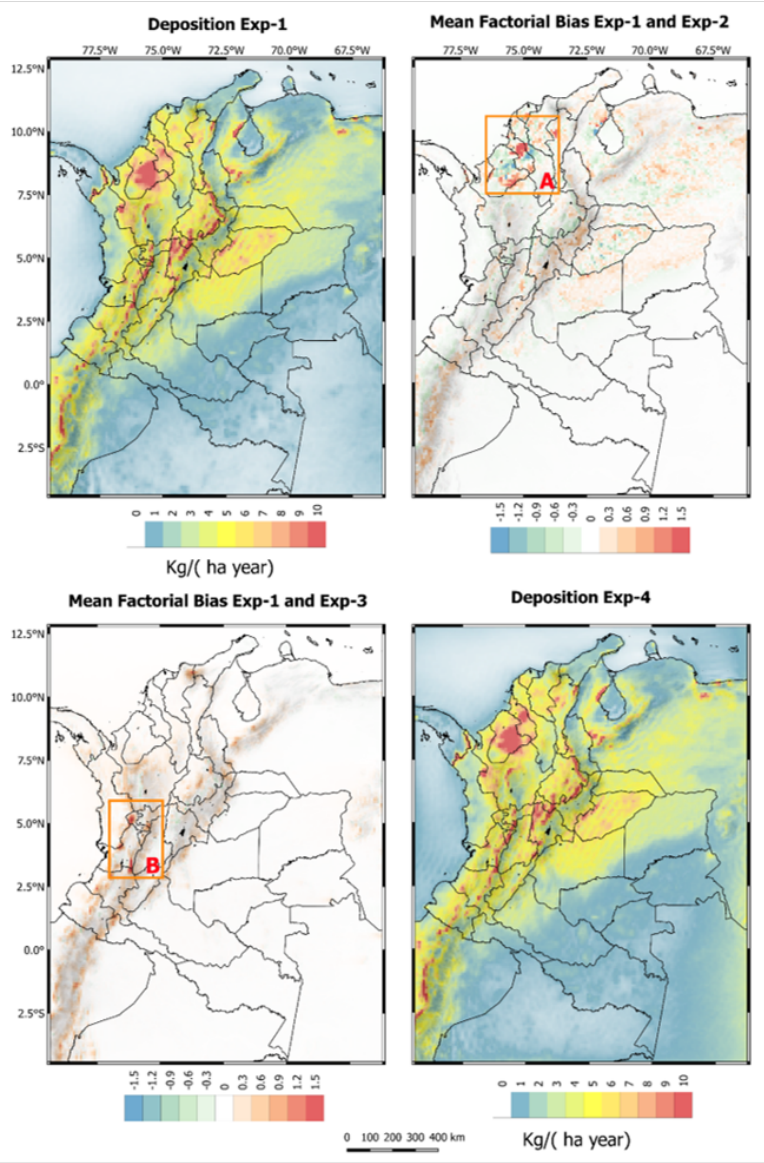

a)
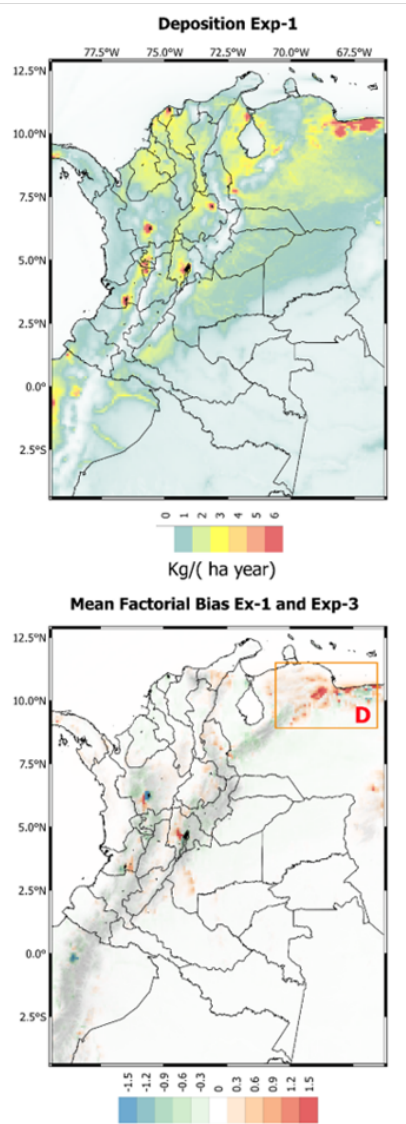

$\underline{0.100200300400 \mathrm{~km}}$

b)
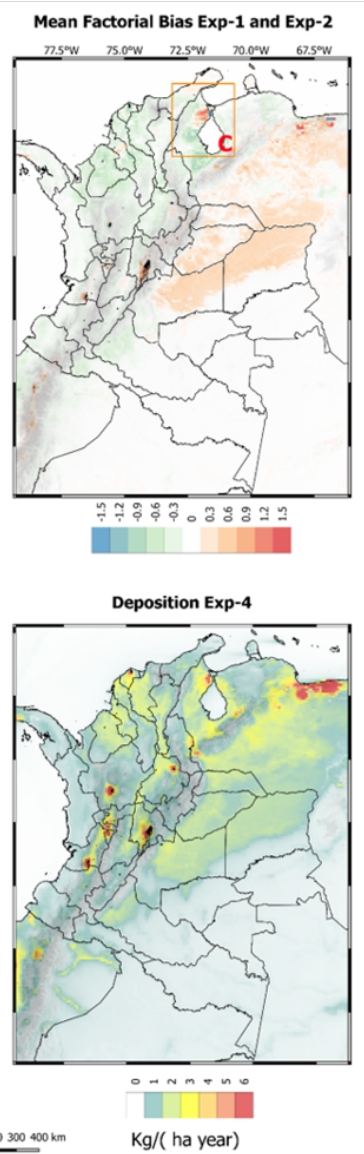

Figure 8. Comparison between the four experimental scenarios with the updating of orography and land cover for three chemical compounds a) the Ammonia $\mathrm{NH}_{3}$, b) the Nitrogen dioxide $\left(\mathrm{NO}_{2}\right)$

use and changed to mosaic cropland, shrub, and grass cover in the new one. In the MFB image, overestimating respect to the Exp-1 conditions is seen in how the dominant land use was changed.

Figure 9 shows the comparison between the deposition velocity and flux for the nine simulation categories. The comparison was made to compare a pixel of a particular zone of interest in a paramo ecosystem named "Paramo de Belmira" located in the northwest of Medellín city. It is possible to see that the change of seasons is significant for the velocity and flux deposition magnitudes Vermeulen and Bleeker (2007) and can differ by close to an order of magnitude between some land-use classes. 

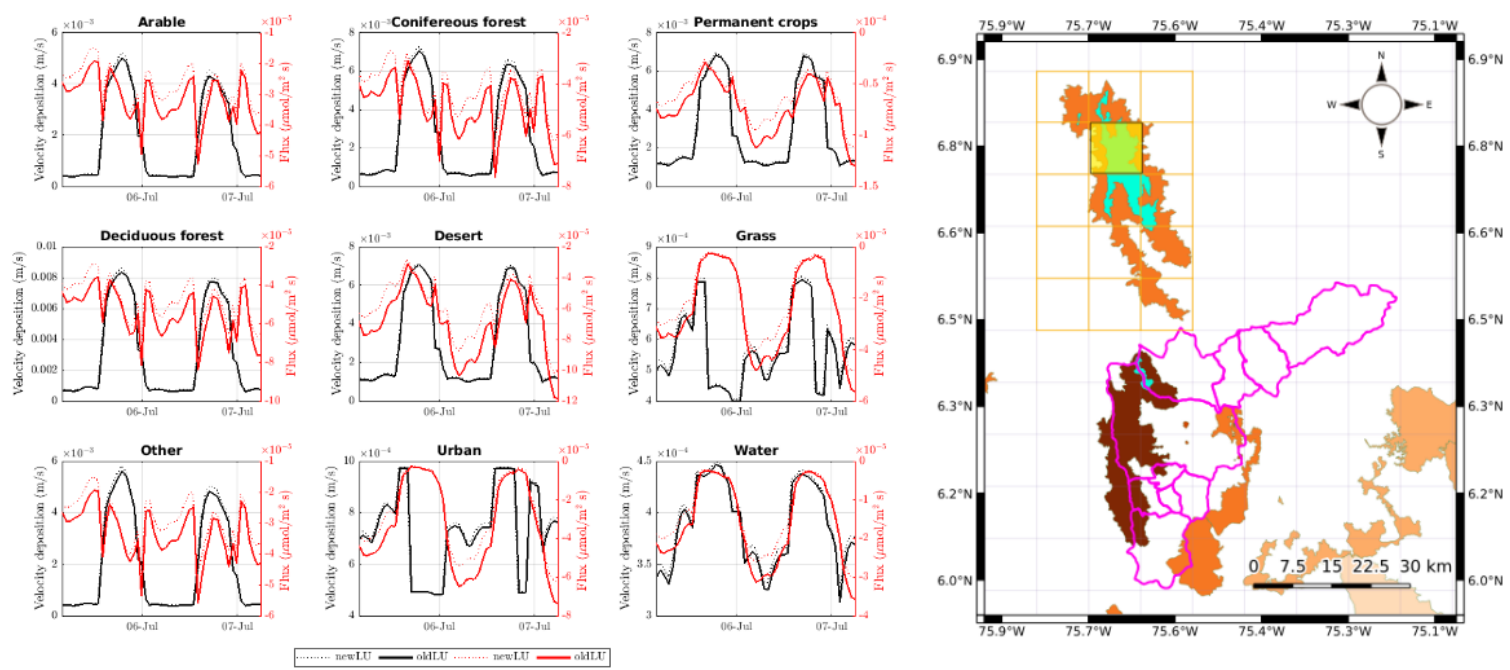

Figure 9. Velocity and flux deposition comparison for the pixel located in the nearest paramo ecosystem from Medellín named "Paramo de Belmira"

\subsection{Point sources experiment}

The LOTOS-EUROS emission module explains the discharge of tracers and aerosols from various sources (anthropogenic, biogenic, marine, airborne dust, fires) that can be configured to define emissions in specific point sources to simulate scenarios. Figure A2 shows the simulation of the total deposition (dry and wet) for Nitrogen taking into account the emission of the four principal cities in Colombia. Cities here were assumed to be point emission sources, which works to determine this city's influence area. Figure (10,A) shows the contours generated with an increment of $5 \mathrm{~g} / \mathrm{ha}$ between contour level and bias correction of $+2 \mathrm{~g} / \mathrm{h} a$ to avoid negative values that appears as a numerical noise from the rest of the reference run minus the punctual perturbed emission run. The more rounded contour delimits the impact zone for each of the cities.

It is possible to identify some wind direction trends for the four different times of the year 2016 (1-9 days of March, June, September, and December). The influence of Barranquilla to faraway zones is perceivable due to the close location of this city to the Caribbean coast, where intense wind conditions exist and flat topography that drives the transport dynamics far away. More of the depositions from Barranquilla is going to the ocean direction and, in other time to the southwest of the city reaching inclusive the other cities deposition areas. For the other cities, the impact area is more limited but with higher deposition values due to the mountainous terrain's roughness and the less magnitude of the wind patterns presented. It is also interesting to see that the deposition from Bogotá could reach other cities as Medellín at some time of the year.

Figure $(10, \mathrm{~B})$ shows a simulation for what happens with Medellín for increase simulation resolution to $0.03 \times 0.03^{\circ}$, conceiving the point source concentrated in a grid cell in the middle of the metropolitan area. The simulation results indicate that the northwest-west area of the Aburra Valley (Medellín and municipalities of the Metropolitan Area) are the most affected, which 


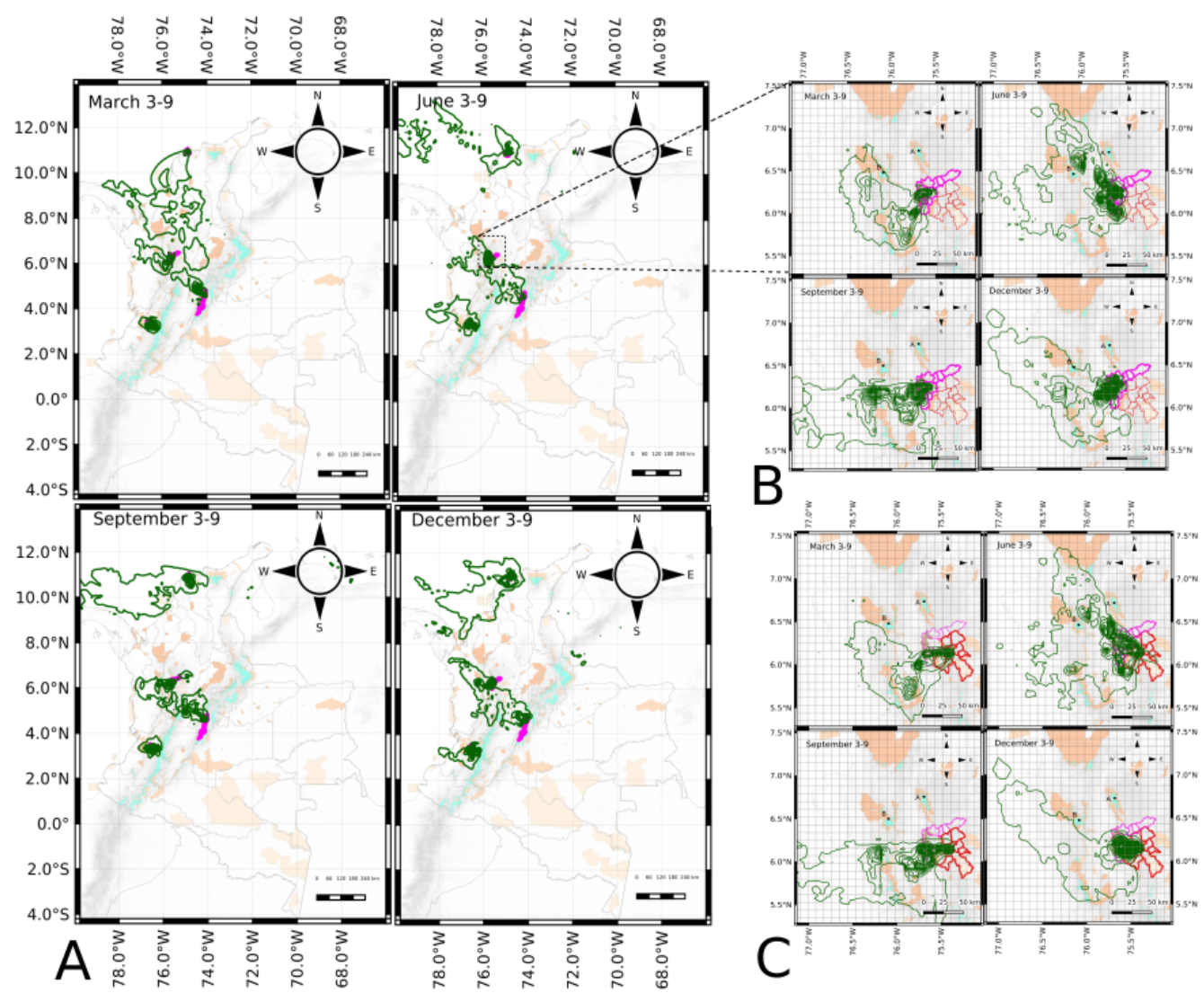

Figure 10. Point source contour experiment for the 4 biggest cities in the country and contour limitation of the influence area

could be seen in how paramos ecosystems located in the points A and B in the map receive nitrogen that was emitted from the cities. In the mosaic in the right part of Fig. $(10, \mathrm{C})$ a detailed simulation, conceiving the point source concentrated now in a grid cell in the middle of the metropolitan Rionegro area. During some parts of the year, it is crucial to notice that Rionegro influences Medellín in its emissions far away depositions. There is a transport dynamic of contaminants that should be studied in more detail because of the increasing Rionegro area for the industrial and urban setting.

\subsection{Protected natural areas}

The Paramos are high-altitude ecosystems that serve as water supplies for a large part of Colombia (Fig. 11, a)). As suppliers of critical ecosystem resources, they are protected under Colombian law. Cartographic data for ecosystems and protected areas were obtained from the Colombian System for Environmental Data (Sistema de Información Ambiental de Colombia, 
This paper is a non-peer reviewed preprint submitted to EarthArXiv. SIAC; http://www.siac.gov.co/). The following picture shows a detailed analysis of the natural protected areas and paramos ecosystems' delimitation, quantifying the model output and the total amount that those areas are receiving.

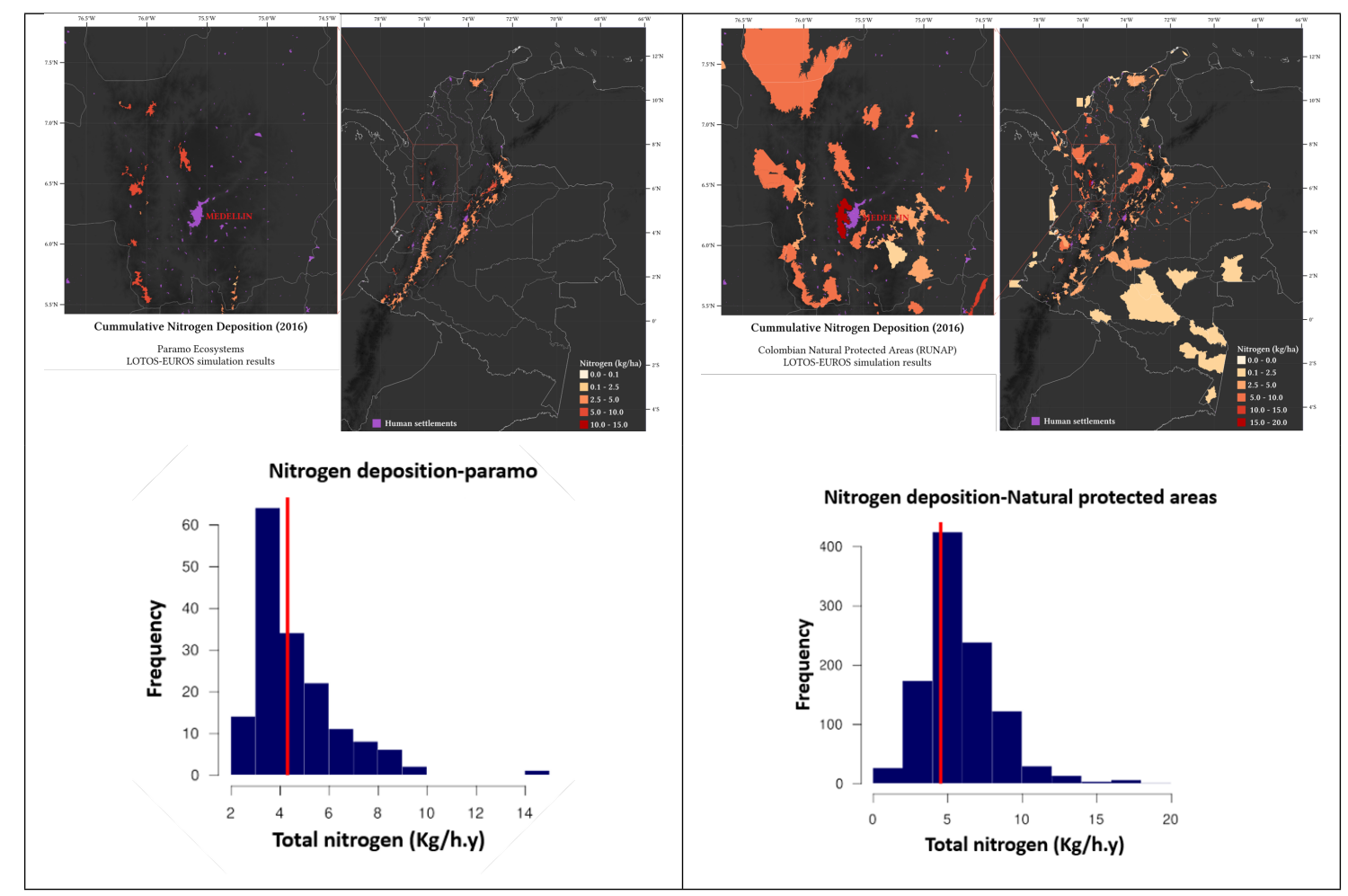

Figure 11. Simulated calculation of annual deposited nitrogen budget for natural protected areas and paramo ecosystem.

The Paramo de Las Baldias was the paramo zone with greater exposure to atmospheric pollutants. It receives $14 \mathrm{~kg} /(\mathrm{ha} \mathrm{yr})$, above the standard critical load of Nr, and above $60 \mathrm{~kg} /(\mathrm{ha} \mathrm{yr})$ of ozone. The paramos of western Antioquia receive 5-6 kg/(ha $\mathrm{yr})$, while the Sonson Paramos are identified as those with the lowest exposure to atmospheric pollutants(2.2-2.6 kg/(ha $\mathrm{yr})$ $\mathrm{Nr}$; 35-40 kg/(ha yr) ozone). The west of the Caribbean coast ecosystems receives the highest ozone load nationwide (50-100 $\mathrm{kg} /($ ha $\mathrm{yr})$ ).

Figure 11 shows a histogram quantification over the natural protected areas and paramo ecosystems to identify the critical deposition load of $\mathrm{NO}_{2}$ in ecosystems and how many areas are at higher risk for the transport of pollutants. The critical load in a tropical ecosystem is not very well determine, and probably, due to the high biodiversity index in this region, the critical load should be less.

\section{Summary and Discussion}

Using the LOTOS-EUROS deposition simulations, we calculated the average annual total nitrogen deposition in Colombia in 2016 estimated as to be $4.2 \mathrm{~kg} /($ ha yr) with min and max values of $(0.8-18.9) \mathrm{kg} /(\mathrm{ha}$ yr). For ozone deposition, the average 
This paper is a non-peer reviewed preprint submitted to EarthArXiv.

annual was 36.0 with min and max values of (7.7-109.4) $\mathrm{kg} /(\mathrm{ha}$ yr), respectively. Within the year, the lowest ozone deposition has been estimated for May and July, while the maximum occurred in June and December-January. Updated protected areas and ecosystem cartography were superposed on simulation results. Weighted average annual total nitrogen deposition in national protected areas and páramos (a critical ecosystem for the water cycle in Colombia) has been estimated to be $2.61 \mathrm{~kg} /(\mathrm{ha} \mathrm{yr}$ ) with min and max values of (0.0-18.5) kg/(ha yr) and $4.11 \mathrm{~kg} /(\mathrm{ha} y r)$ and min and max values of (2.2-14.2) $\mathrm{kg} /(\mathrm{ha} \mathrm{yr}$ ), respectively. Total nitrogen deposition at or above $5 \mathrm{~kg} /(\mathrm{ha} \mathrm{yr}$ ) occurs in $60 \%$ of declared protected areas and over $13 \%$ of the páramo ecosystems. Weighted average annual total ozone deposition in nationally protected areas and páramos has been estimated on $19.8 \mathrm{~kg} /$ (ha yr) with min and max values (0.0-99.3) kg/(ha yr) and $24.8 \mathrm{~kg} /$ (ha yr) with min and max (13.2-62.4) kg/(ha yr), respectively.

\section{Conclusions}

This work's main contribution is assessing the LOTOS-EUROS CTM Model's performance in the Tropical Andes Domain, focusing the analysis on deposition simulations. Determining the relevance of the Land Use Land Cover and Topography as model inputs paying attention to specific points of the study zone were specific factors driving the deposition process was one of this work result.

Although LOTOS-EUROS is terrain following, the chosen domain simulations are sensitive to the orography map, which needs to be a high resolution only if the simulation is also high resolution. We also know that the EDGAR inventory does not represent some component emission dynamics appropriately. For the time of the experiments, this was the inventory we had available for the study domain; through other works, we are working on an updating of the inventory employing parameter estimation using data assimilation and top-down reconstruction methodology (Santiago Lopez-Restrepoa, 2020)

Deposition depends on land-use changes. It was essential to analyze the area of interest's temporal behavior to identify zones with over and subs estimation compared with the early reference. Natural protected areas with notable changes in deposition between the default and updated input data were identified, emphasizing the importance of using up-to-date and accurate land cover data in the simulation model. Vulnerable areas like natural protected areas and paramos ecosystems may require more than a local conservation effort to preserve their ecological functions.

Simulations with point sources identified the transport patterns in the territory. They showed the regional influence of the significant cities in the base of qualitative and quantitative results to understand the dynamics of emission and deposition of contaminants for the principal cities of Colombia, which consist in an attractive information supply to start understanding the transport of atmospheric contaminants over this territory. The atmospheric transport and deposition of pollutants present ecosystem risk factors that require an evaluation of impacts directly in the field based on the reported results and their inclusion in conservation strategies. 
This paper is a non-peer reviewed preprint submitted to EarthArXiv.

Code availability. One of the results of this work is the new land use generated for this study domain. the netcdf file is added to the submission of this work

\section{Appendix A}

Figure A1 shows the comparison between the two orography scenarios input to the model (the images at the left) against the four different run simulation resolution $\left(0.12^{\circ}, 0.09,0.06,0.12\right)$. Although the CTM is terrain following, the simulations are insensitive to the orography change map when the simulation needs to be computed in high resolution. For no necessary high resolutions for the simulation, the change in orography is not relevant because the interpolation softens the differences.

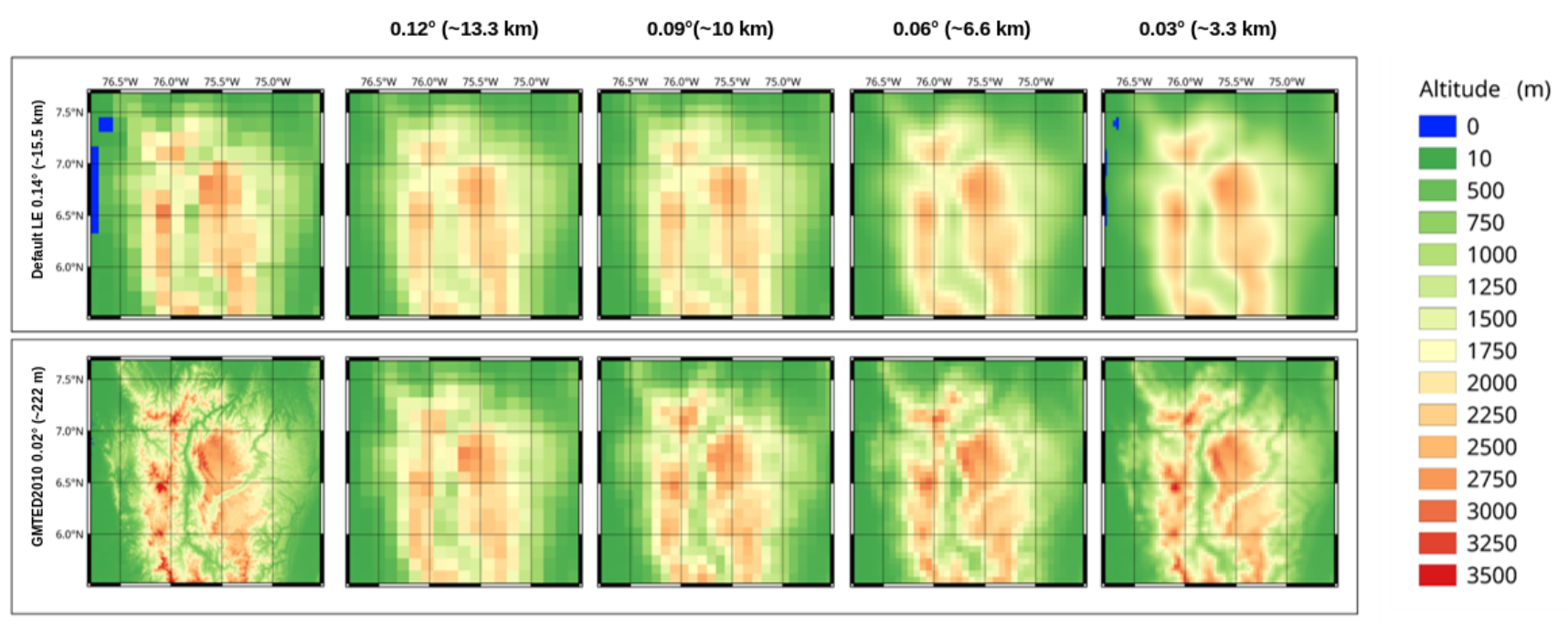

Figure A1. Comparison between the custom LOTOS-EUROS (coarse) and the GMTED (fine) topographies for different simulation resolutions

\section{A1}

Author contributions. TEXT

Andres Yarce Botero (orcid=0000-0003-1441-2367) is the corresponding author. Conceptualization, Methodology, Software, Writing - Original Draft. Santiago Lopez-Restrepo (orcid=0000-0002-7637-1575) Methodology, Software. Nicolas 
This paper is a non-peer reviewed preprint submitted to EarthArXiv.

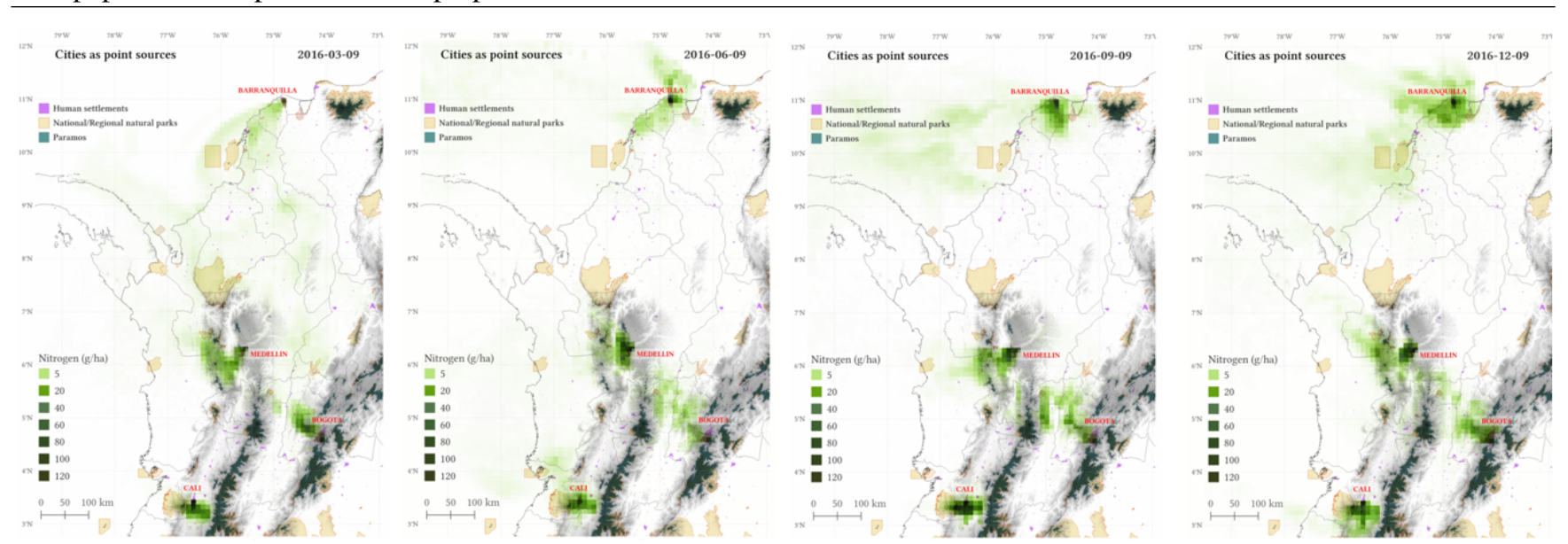

Figure A2. Point source experiment over the 4 biggest cities from Colombia. Nitrogen emission Resolution of the simulation $\left(0.09 \times 0.09^{\circ}\right)$

280 Pinel (orcid=0000-0003-1304-3096) Conceptualization, Methodology, Analysis, Writing - Review \& Editing. O. L. Quintero (orcid=0000-0002-8697-4361) Conceptualization, Methodology. Arjo Segers (orcid=0000-0002-1319-0195) Methodology, Software, Writing - Review \& Editing. A. W. Heemink (orcid=0000-0001-8559-9566) Conceptualization, Supervision

Competing interests. TEXT

Disclaimer. TEXT

Acknowledgements. Authors want to acknowledge Centro de Computación Cientifica APOLO at Universidad EAFIT, TNO, TU Delft University for their incomparable support and express acknowledge to the ESA CCI Land Cover project for provide the updated land use for the area of study 


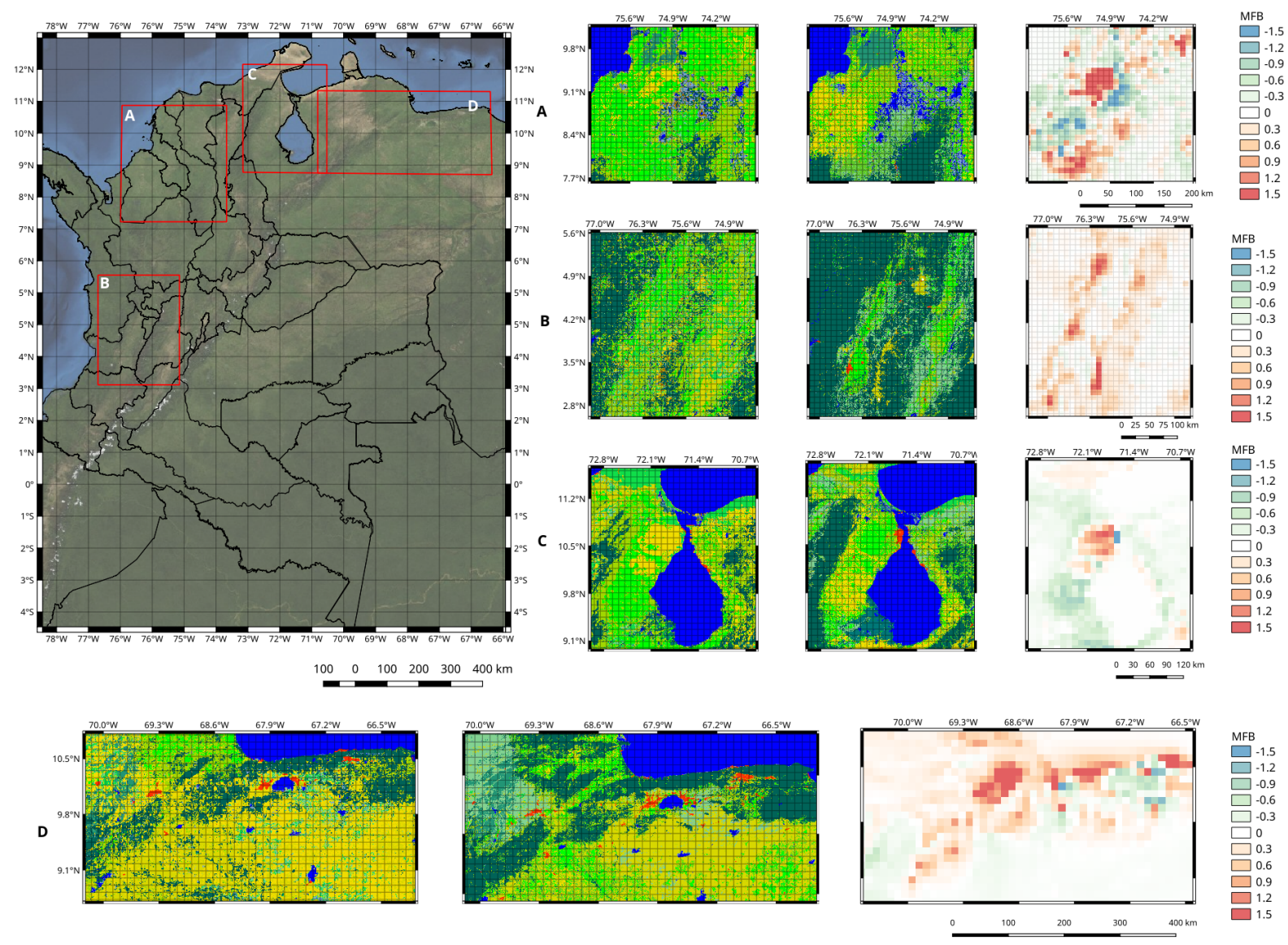

Figure A3. Comparison between the changes in land use for the $\mathrm{NH}_{3}$ and $\mathrm{NO}_{2}$ deposition results of Figure 8 for 6 regions

\section{References}

Bard, S. M.: Global transport of anthropogenic contaminants and the consequences for the Arctic marine ecosystem, Marine Pollution

Bulletin, 38, 356-379, 1999.

Barten, J. G. M., Ganzeveld, L. N., Visser, A. J., Jiménez, R., and Krol, M. C.: Evaluation of nitrogen oxides sources and sinks and ozone production in Colombia and surrounding areas, Atmospheric Chemistry and Physics Discussions, 2019, 1-30, https://doi.org/10.5194/acp2019-781, 2019.

Bobbink, R., Hicks, K., Galloway, J., Spranger, T., Alkemade, R., Ashmore, M., Bustamante, M., Cinderby, S., Davidson, E., Dentener, F.,

Emmett, B., Erisman, J.-W., Fenn, M., Gilliam, F., Nordin, a., Pardo, L., and De Vries, W.: Global assessment of nitrogen deposition 
This paper is a non-peer reviewed preprint submitted to EarthArXiv.

effects on terrestrial plant diversity: a synthesis., Ecological applications : a publication of the Ecological Society of America, 20, 30-59, https://doi.org/10.1890/08-1140.1, 2010.

Brasseur, G. P., Xie, Y., Petersen, K., Bouarar, I., Flemming, J., Gauss, M., Jiang, F., Kouznetsov, R., Kranenburg, R., Mijling, B., et al.: Ensemble forecasts of air quality in eastern China-Part 1: Model description and implementation of the MarcoPolo-Panda prediction system, version 1, Geoscientific Model Development, 12, 33-67, 2019.

Casallas, A., Celis, N., Ferro, C., Barrera, E. L., Peña, C., Corredor, J., and Segura, M. B.: Validation of PM 10 and PM 2.5 early alert in Bogotá, Colombia, through the modeling software WRF-CHEM, Environmental Science and Pollution Research, pp. 1-11, 2020.

Chérin, N., Roustan, Y., Musson-Genon, L., and Seigneur, C.: Modelling atmospheric dry deposition in urban areas using an urban canopy approach, Geoscientific Model Development, 8, 893-910, https://doi.org/10.5194/gmd-8-893-2015, revue OA, lien vers le full-text : http://www.geosci-model-dev.net/8/893/2015/gmd-8-893-2015.pdf, 2015.

Danielson, J. and Gesch, D.: Global Multi-resolution Terrain Elevation Data 2010(GMTED2010), U.S. Geological Survey Open-File Report 2011-1073, 2010, 26, https://doi.org/citeulike-article-id:13365221, 2011.

Defourny, P., Moreau, I., and Bontemps, S. e. a.: P Roduct U Ser G Uide, Tech. rep., UCL, Gamma remote sensing, 2017.

Di Gregorio, A.: Land cover classification system: classification concepts and user manual: LCCS, vol. 2, Food \& Agriculture Org., 2005.

Dominguez-Rodriguez, A., Baez-Ferrer, N., Rodríguez, S., Avanzas, P., Abreu-Gonzalez, P., Terradellas, E., Cuevas, E., Basart, S., and Werner, E.: Saharan Dust Events in the Dust Belt-Canary Islands-and the Observed Association with in-Hospital Mortality of Patients with Heart Failure, Journal of Clinical Medicine, 9, 376, 2020.

Droppo, J. G.: Improved formulations for air-surface exchanges related to National Security Needs: dry deposition models, Tech. rep., Pacific Northwest National Lab.(PNNL), Richland, WA (United States), 2006.

Duce, R. A., LaRoche, J., Altieri, K., Arrigo, K. R., Baker, A. R., Capone, D. G., Cornell, S., Dentener, F., Galloway, J., Ganeshram, R. S., Geider, R. J., Jickells, T., Kuypers, M. M., Langlois, R., Liss, P. S., Liu, S. M., Middelburg, J. J., Moore, C. M., Nickovic, S., Oschlies, A., Pedersen, T., Prospero, J., Schlitzer, R., Seitzinger, S., Sorensen, L. L., Uematsu, M., Ulloa, O., Voss, M., Ward, B., and Zamora, L.: Impacts of atmospheric anthropogenic nitrogen on the open ocean, Science, 320, 893-897, https://doi.org/10.1126/science.1150369, 2008.

Erisman, J. W., Vermeulen, A., Hensen, A., Flechard, C., Dämmgen, U., Fowler, D., Sutton, M., Grünhage, L., and Tuovinen, J. P.: Monitoring and modelling of biosphere/atmosphere exchange of gases and aerosols in Europe, Environmental Pollution, 133, 403-413, https://doi.org/10.1016/j.envpol.2004.07.004, 2005.

Erisman, J. W., Galloway, J. N., Seitzinger, S., Bleeker, A., Dise, N. B., Petrescu, A. M. R., Leach, A. M., and de Vries, W.: Consequences of human modification of the global nitrogen cycle., Philosophical transactions of the Royal Society of London: Series B, Biological Sciences, 368, 20130 116, https://doi.org/10.1098/rstb.2013.0116, 2013.

Eva, H. D., De Miranda, E., Di Bella, C. M., Gond, V., Huber, O., Sgrenzaroli, M., Jones, S., Coutinho, A. R., Dorado, A., Guimarães, M., et al.: A vegetation map of South America, European Commission, 2002.

Farrer, E. C. and Suding, K. N.: Teasing apart plant community responses to N enrichment: the roles of resource limitation, competition and soil microbes, Ecology letters, 19, 1287-1296, https://doi.org/10.1111/ele.12665, 2016.

Fowler, D., Cape, J. N., Coyle, M., Flechard, C., Kuylenstierna, J., Hicks, K., Derwent, D., Johnson, C., and Stevenson, D.: The global exposure of forests to air pollutants, Water, Air, and Soil Pollution, 116, 5-32, 1999.

Fowler, D., Coyle, M., Skiba, U., Sutton, M. a., Cape, J. N., Reis, S., Sheppard, L. J., Jenkins, A., Grizzetti, B., Galloway, J. N., Vitousek, P., Leach, A., Bouwman, a. F., Butterbach-Bahl, K., Dentener, F., Stevenson, D., Amann, M., and Voss, M.: The global nitrogen cy- 
This paper is a non-peer reviewed preprint submitted to EarthArXiv.

cle in the twenty-first century, Philosophical transactions of the Royal Society of London: Series B, Biological Sciences, 368, 1-13, https://doi.org/10.1098/rstb.2013.0164, 2013.

Fritz, S., Bartholome, E., Belward, A., Hartley, A., Stibig, H.-J., Eva, H., Mayaux, P., Bartalev, S., Latifovic, R., Kolmert, S., et al.: Harmonisation, mosaicing and production of the Global Land Cover 2000 database, JRC report EUR, 20849, 2003.

Giardina, M. and Buffa, P.: A new approach for modeling dry deposition velocity of particles, Atmospheric Environment, 180, 11-22, https://doi.org/10.1016/j.atmosenv.2018.02.038, 2018.

Gonzalez, C. M., Gomez, C. D., Rojas, N. Y., Acevedo, H., and Aristizabal, B. H.: Relative impact of on-road vehicular and point-source industrial emissions of air pollutants in a medium-sized Andean city, Atmospheric Environment, 152, 279-289, https://doi.org/10.1016/j.atmosenv.2016.12.048, 2017.

Graaf, S. C., Dammers, E., Schaap, M., and Erisman, J. W.: How are NH 3 dry deposition estimates affected by combining the LOTOSEUROS model with IASI-NH 3 satellite observations?, Atmospheric Chemistry and Physics, 18, 13 173-13 196, 2018.

Grajales, J. F. and Baquero-Bernal, A.: Inference of surface concentrations of nitrogen dioxide (NO2) in Colombia from tropospheric columns of the ozone measurement instrument (OMI), Atmósfera, 27, 193-214, 2014.

Henao, J. J., Mejía, J. F., Rendón, A. M., and Salazar, J. F.: Sub-kilometer dispersion simulation of a CO tracer for an inter-Andean urban valley, Atmospheric Pollution Research, 11, 928-945, https://doi.org/10.1016/j.apr.2020.02.005, 2020.

Hendriks, C., Kranenburg, R., Kuenen, J., van Gijlswijk, R., Wichink Kruit, R., Segers, A., Denier van der Gon, H., and Schaap, M.: The origin of ambient particulate matter concentrations in the Netherlands, Atmospheric Environment, 69, 289-303, https://doi.org/10.1016/j.atmosenv.2012.12.017, 2013.

Jia, Y., Yu, G., Gao, Y., He, N., Wang, Q., Jiao, C., and Zuo, Y.: Global inorganic nitrogen dry deposition inferred from ground- and spacebased measurements., Scientific Reports, 6, 19810, https://doi.org/10.1038/srep19810, 2016.

Kaiser, J. W., Heil, A., Andreae, M. O., Benedetti, A., Chubarova, N., Jones, L., Morcrette, J. J., Razinger, M., Schultz, M. G., Suttie, M., and Van Der Werf, G. R.: Biomass burning emissions estimated with a global fire assimilation system based on observed fire radiative power, Biogeosciences, 9, 527-554, https://doi.org/10.5194/bg-9-527-2012, 2012.

Kociok, T., February, F., Grossmann, P., Sprung, D., van Eijk, A., and Stein, K.: Investigation of aerosols in South Africa: Comparison of measurements and modeling, in: Environmental Effects on Light Propagation and Adaptive Systems, vol. 10787, p. 1078704, International Society for Optics and Photonics, 2018.

Koerner, S. E., Avolio, M. L., La Pierre, K. J., Wilcox, K. R., Smith, M. D., and Collins, S. L.: Nutrient additions cause divergence of tallgrass prairie plant communities resulting in loss of ecosystem stability, Journal of Ecology, 104, 1478-1487, https://doi.org/10.1111/1365$2745.12610,2016$.

Krupa, S.: Effects of atmospheric ammonia (NH3) on terrestrial vegetation: a review, Environmental pollution, 124, 179-221, 2003.

Lopez-Restrepo, S., Yarce, A., Pinel, N., Quintero, O., Segers, A., and Heemink, A.: Forecasting $\mathrm{PM}_{10}$ and $\mathrm{PM}_{2.5}$ in the Aburrá Valley (Medellín, Colombia) via EnKF based data assimilation, Atmospheric Environment, 232, 117507, https://doi.org/10.1016/j.atmosenv.2020.117507, 2020.

Manders-Groot, A. M. M., Segers, A. J., Jonkers, S., Schaap, M., Timmermans, R., Hendriks, C., Sauter, F., Kruit, R. W., Swaluw, E. V. D., Eskes, H., and Banzhaf, S.: LOTOS-EUROS v2.0 Reference Guide. TNO 2016 R10, TNO Innovation for life, 2016a.

Manders-Groot, A. M. M., Segers, A. J., Jonkers, S., Schaap, M., Timmermans, R., Hendriks, C., Sauter, F., Kruit, R. W., Swaluw, E. V. D., Eskes, H., and Banzhaf, S.: LOTOS-EUROS v2.0 Reference Guide. TNO 2016 R10, TNO Innovation for life, 2016b. 
This paper is a non-peer reviewed preprint submitted to EarthArXiv.

Marécal, V., Peuch, V. H., Andersson, C., Andersson, S., Arteta, J., Beekmann, M., Benedictow, A., Bergstrem, R., Bessagnet, B., Cansado, A., Chiroux, F., Colette, A., Coman, A., Curier, R. L., Van Der Gon, H. A. C. D., Drouin, A., Elbern, H., Emili, E., Engelen, R. J., Eskes, H. J., Foret, G., Friese, E., Gauss, M., Giannaros, C., Guth, J., Joly, M., Jaumouill, E., Josse, B., Kadygrov, N., Kaiser, J. W., Krajsek, K., Kuenen, J., Kumar, U., Liora, N., Lopez, E., Malherbe, L., Martinez, I., Melas, D., Meleux, F., Menut, L., Moinat, P., Morales, T., Parmentier, J., Piacentini, A., Plu, M., Poupkou, A., Queguiner, S., Robertson, L., Roul, L., Schaap, M., Segers, A., Sofiev, M., Tarasson, L., Thomas, M., Timmermans, R., Valdebenito, Van Velthoven, P., Van Versendaal, R., Vira, J., and Ung, A.: A regional air quality forecasting system over Europe: The MACC-II daily ensemble production, Geoscientific Model Development, 8, 2777-2813, https://doi.org/10.5194/gmd-8-2777-2015, 2015.

Mårtensson, E., Nilsson, E., de Leeuw, G., Cohen, L., and Hansson, H.-C.: Laboratory simulations and parameterization of the primary marine aerosol production, Journal of Geophysical Research: Atmospheres, 108, 2003.

Maskell, L. C., Smart, S. M., Bullock, J. M., Thompson, K., and Stevens, C. J.: Nitrogen deposition causes widespread loss of species richness in British habitats, Global Change Biology, 16, 671-679, https://doi.org/10.1111/j.1365-2486.2009.02022.x, 2010.

Monahan, E. C., Spiel, D. E., and Davidson, K. L.: A Model of Marine Aerosol Generation Via Whitecaps and Wave Disruption, Oceanographic Sciences Library SPRINGER, 2, 167-174, https://doi.org/10.1007/978-94-009-4668-2_16, 1986.

Nedbor-Gross, R., Henderson, B. H., Pérez-Peña, M. P., and Pachón, J. E.: Air quality modeling in Bogotá Colombia using local emissions and natural mitigation factor adjustment for re-suspended particulate matter, Atmospheric Pollution Research, 9, 95-104, https://doi.org/10.1016/j.apr.2017.07.004, 2018.

Pachón, J. E., Galvis, B., Lombana, O., Carmona, L. G., Fajardo, S., Rincón, A., Meneses, S., Chaparro, R., Nedbor-Gross, R., and Henderson, B.: Development and evaluation of a comprehensive atmospheric emission inventory for air quality modeling in the megacity of Bogotá, Atmosphere, 9, 1-17, https://doi.org/10.3390/atmos9020049, 2018.

Petersen, K., Brasseur, G. P., Bouarar, I., Flemming, J., Gauss, M., Jiang, F., Kouznetsov, R., Kranenburg, R., Mijling, B., Peuch, V.-H., et al.: Ensemble forecasts of air quality in eastern China-Part 2: Evaluation of the MarcoPolo-Panda prediction system, version 1, Geoscientific Model Development, 12, 1241-1266, 2019.

Quintero Montoya, O. L., Niño-Ruiz, E. D., and Pinel, N.: On the mathematical modelling and data assimilation for air pollution assessment in the Tropical Andes, Environmental Science and Pollution Research, https://doi.org/10.1007/s11356-020-08268-4, 2020.

Santiago Lopez-Restrepoa, Andres Yarce, N. P. O. L. Q. A. S. A. W. H.: Forecasting PM10and PM2.5in the Aburrá Valley (Medellín,10Colombia) via EnKF based Data Assimilation, Elsevier, 2020.

Simkin, S. M., Allen, E. B., Bowman, W. D., Clark, C. M., Belnap, J., Brooks, M. L., Cade, B. S., Collins, S. L., Geiser, L. H., Gilliam, F. S., Jovan, S. E., Pardo, L. H., Schulz, B. K., Stevens, C. J., Suding, K. N., Throop, H. L., and Waller, D. M.: Conditional vulnerability of plant diversity to atmospheric nitrogen deposition across the United States, Proceedings of the National Academy of Sciences of the United States of America, 113, 4086-4091, https://doi.org/10.1073/pnas.1515241113, 2016.

Stevens, C. J., Dise, N. B., Mountford, J. O., and Gowing, D. J.: Impact of Nitrogen Deposition Grasslands, Science, 303, 1876-1880, 2004.

Timmermans, R., Kranenburg, R., Manders, A., Hendriks, C., Segers, A., Dammers, E., Zhang, Q., Wang, L., Liu, Z., Zeng, L., et al.: Source apportionment of PM2. 5 across China using LOTOS-EUROS, Atmospheric Environment, 164, 370-386, 2017.

UPB and AMVA: Inventario de Emisiones Atmosféricas del Valle de Aburrá - actualización 2015, Tech. rep., Universidad Pontificia Bolivariana - Grupo de Investigaciones Ambientales, Area Metropolitana del Valle de Aburra, Medellín, https://www.metropol.gov.co/ambiental/ calidad-del-aire/Documents/Inventario-de-emisiones, 2017. 
This paper is a non-peer reviewed preprint submitted to EarthArXiv.

Van Zanten, M., Sauter, F., RJ, W. K., Van Jaarsveld, J., and Van Pul, W.: Description of the DEPAC module: Dry deposition modelling with DEPAC_GCN2010, RIVM rapport 680180001, 2010.

410 Verkaik, J. and Ganzeveld, L.: Evaluation of Colombian Methane Emissions Combining WRF-Chem and TROPOMI, Wageningen University and Research, Meteorology and air quality, MSc Thesis, 2019.

Vermeulen, A. and Bleeker, A.: Dry deposition of acidifying components on forest, ECN, Petten. ECN report E-07e077, 2007.

Wesely, M.: Parameterization of surface resistances to gaseous dry deposition in regional-scale numerical models, Atmospheric Environment (1967), 23, 1293-1304, 1989.

415 Zhang, L., Gong, S., Padro, J., and Barrie, L.: A size-segregated particle dry deposition scheme for an atmospheric aerosol module, Atmospheric Environment, 35, 549-560, 2001. 